\title{
EFFECTIVENESS OF INTER-HEALTH PROFESSIONAL COLLABORATION FOR AN IMPROVED MANAGEMENT OF IN-PATIENT CARE AT AN NI'MAH WANGON HOSPITAL
}

\author{
Ratna Widarastuti, Wiwik Kusumawati
}

Masters Program in Hospital Management, Universitas Muhammadiyah Yogyakarta

\begin{abstract}
Background: An Ni'mah Hospital is a type D hospital located in Banyumas, Central Java. Obstetric and gynecologic services are the main services provided with birth delivery, curettage, and caesarian section, as the most common services. The hospital is financed under the Indonesian National Health Insurance (JKN, BPJS) payment scheme, and it often experiences loss. Recently, the hospital management has implemented a new policy, namely inter-health professional collaboration, which aims to improve hospital performance. This study aimed to examine the effectiveness of inter-health professional collaboration on the improvement of in-patient care management at An Ni'mah Wangon Hospital.

Subjects and Method: This was a mixed method study carried out at An Ni'mah Wangon Hospital, Banyumas, Central Java. A sample of informants was selected for this study, consisting of gynecologists, general practitioners, nurses, midwives, pharmacists, and nutritionists. The data were collected by questionnaire, interview, observation, and document review. Quantitative and qualitative data were integrated by triangulation to increase data credibility.

Results: Paramedics had practiced inter-health professional collaboration. However, inter-health professional communication remained a point of concern due to some hospital internal problem. Paramedics at the medical record unit had worked according to the Standard Operating Procedure (SOP). Overall, patients were satisfied with the collaboration process. However, paramedics in the in-patient unit had not comply with the clinical pathway. The pharmacy and the nutrition units were under-staffed.

Conclusion: The collaboration process has not been fully implemented due to some hospital internal problem. However, overall the patients are satisfied with the inter-health professional collaboration. Paramedics have not implemented clinical pathway, which may lead to in-effective service and some losses to hospital.
\end{abstract}

Keywords: inter-health professional, collaboration, management, in-patient care, hospital

\section{Correspondence:}

Ratna Widarastuti. Masters Program in Hospital Management, Universitas Muhammadiyah Yogyakarta, Jl. Lingkar Selatan, Tamantirto, Kasihan, Bantul, Yogyakarta. Email: rwidarastuti@gmail.com. Mobile: 08122679186 